\title{
Influence of High-Performance Work System on Employee Service Performance and OCB: The Mediating Role of PsyCap
}

\author{
Kashif Nadeem (Corresponding Author) \\ National University of Modern Languages, Islamabad, Pakistan \\ E-mail: knciit@hotmail.com
}

Amir Riaz

COMSATS University, Lahore, Pakistan

Yasir Iftikhar

National College of Business Administration \& Economics, Lahore, Pakistan

Muhammad Bilal Ahmad

Assistant Director, University of Education, Dera Ghazi Khan

Waqas Shamshad

National University of Modern Languages

Received: May 10, 2019 Accepted: June 29, 2019 Published: July 1, 2019

doi:10.5296/ieb.v5i2.15009ＵRL: https://doi.org/10.5296/ieb.v5i2.15009

\begin{abstract}
High-performance work system (HPWS) has been viewed as black-box over the last decade and there is a need for better understanding of the mechanism through which employee performance can be enhanced significantly. Based on the 371 samples collected from banking, insurance, airline, telecommunication, and hospitality, this study provides empirical evidence that HPWS positively influence the service performance of employees and PsyCap mediates the relationship of high-performance work system and employee service performance, OCB
\end{abstract}


among service sector employees of Pakistan. The implications of this study conclude the findings in detail.

Keywords: High-performance work system, Employee performance, Service sector, Psychological capital

\section{Introduction}

Globalization and intense competition compelled organizations to adopt new ways to enhance their performance internally. From all the internal resources, human competencies are unmatched, inimitable and can be a greater source of competitive advantage Barney \& Wright (1998). From the resource-based view (RBV) of firms (Barney \& Wright, 1998) and social exchange theory (Blau, 1964), research on strategic human resource management (SHRM) has gained much attention to increasing organizational performance through their workforce

A major challenge faced by today's managers is to manage the human resources for maximum productivity and enhancement their creativity with minimum cost. To cope that challenge, a research stream titled strategic human resource management (SHRM), which has implemented to establish the mechanism in which human resource management practices in form of system increase the overall effectiveness of the firm (Ferris et al., 1998). One latest emerging approach of SHRM is calledHigh-Performance Management (Appelbaum et al., 2000). The core objective of this new approach High- Performance Management is to equip the workforce with creativity, ingenuity, and problem-solving ability by focusing on quality and adapt rapidly to changing conditions. These features of HPWS are the major source of competitive advantage for an organization and improve the performance at organizational-level (Datta et al., 2005; Wright et al., 2003). Collins and Smith (2006) contended that HPWS positively influence organizational performance through creating an environment which provokes behaviors and capabilities of employees that add value to the firm competitive advantage.

From the employee perspective, previous studies have examined the influence of HPWS on employee attitude and behavior (Kroon et al., 2009; Tang \& Tang, 2012; Miao et al., 2015). Researchers have reported that HPWS has positive relationship with desired employee attitudes and behavior such as job satisfaction (Dyer \& Reeves, 1995), affective commitment, OCB (Kehoe \& Wright, 2013) and occupational safety (Zacharato et al., 2005) and negatively related to undesired outcomes including employee turnover (Guthrie, 2001; Huselid, 1995; Batt, 2002), voluntary turnover (Guthrie et al., 2009) intention to quit, and absenteeism (Guthrie et al., 2009; Kehoe \& Wright, 2013) and employee burnout (Kroon et al., 2009).

The recent growth of the Pakistani service sector demands the great attention of employee performance due to its direct linkage with organizational performance. This study among the pioneer attempts to suggest the mechanism through which HPWS link the employee service performance and OCB in the service sector of Pakistan. The mediating role of PsyCap in this relationship has also been investigated empirically.

\section{Literature Review and Hypothesis}

\subsection{HPWS and Employee Service Performance}


Research in the field of HRM has introduced its latest approach called high-Performance Management (Appelbaum et al., 2000). SHRM theorists have identified the human resource practices which can enhance performance are named as HPWS (Huselid, 1995) which includes, i.e., selectivity, training, incentive compensation, flexible work arrangements, and employee participation. Takeuchi et al. (2009) defined the HPWS "is a group of separate but interconnected HR management practices designed to enhance employee and firm performance outcomes through improving workforce competence, attitude, and motivation".

From the social exchange theory's perspectives (Blau, 1964), HRM practices stimulate employees from where they start to reciprocate the positive or negative behavior based upon the snapshots they establish about the implementation of HR practices (Nishii et al., 2008). Due to their nature and implementation, high-performance work practices affect the norms and expectations which go beyond the specific behavior for which they are designed (Singh, 2009).

Employee work performance has gained vital importance in the management literature due to its direct link with organizational performance in today highly competitive market. Employee performance is the behavior, "that are related to organizational goals and that particular behavior are under the good control of employees (Campbell et al., 1993)".

In services industries, frontline employees play a vital role in the delivery of customer value during the service encounter process. Heskett et al. (1997) argued that it is no doubt that frontline employees are of paramount importance to high-quality service and customer satisfaction and loyalty are determined by satisfied employees. Earlier studies found that employee' performance or behaviors have strongly related to customer satisfaction and customers' evaluation of service quality (Schneider \& Bowen, 1993; Schneider, 2004). Furthermore, Likewise the employee's general performance (task and contextual), an employee's service performance is also comprised ofthe task and contextual service performance (Borman \& Motowidlo, 1993). In the service encounter context, task performance refers to the service production and delivery activities directly related to efficiency, and contextual performance refers to the supportive activities to customers and organizations, or social environment. Bettencourt and Brown (1997) defined this contextual service behavior (also named as extra-role customer service) "discretionary behavior of contact employees in serving customers that extend beyond formal role requirements".

In the context of service, customers have been viewed as a significant factor in determining the employee performance (Bowen \& Waldman, 1999) and the quality of the contact among frontline employees and customer's role is critical in shaping the customer satisfaction. Thus, during the customer interaction, employee behavior has a significant role in the determination of customer's perception about service quality.

Researchers argued that the impact of HPWS varies with the change of context and there isa challenge to identify the ideal context in which maximum influence of HPWS on the organizational performance is achieved. Datta, Guthrie and Wright, (2005) pointed out that industry can be the important moderator that deserves attention in the literature. It seems that HPWS would benefit the service organizations most because service sector employees have more decision making authority than the manufacturing employees (Rosenthal et al., 1997), and employee's motivation to exert discretionary efforts is the most significant contribution 
of HPWS (Bailey, 1993). Employees working in the service sector are in indirect link with customers, thus the overall influence of HPWPs on the behavior of service sector employees should more positively influence service quality (Batt, 2002). Datta et al. (2005) argued that due to the frequent customer contact and high discretionary behavior in the service industry, the effect of HPWS is greater. Following the above discussion, the present study not only confirms the empirical impact of HPWS on the service performance but also on employee discretionary efforts (OCB) in the service sector of Pakistan.

Mills et al. (1983) argued that direct customer contact also strengthened the motivation level of employees. Having desire to exchange the pleasant customer interaction (Erickson et al., 2006), satisfaction received from successful co-production (Van Dolen et al., 2004) and fear of negative interpersonal evaluations (Baumeister, 1982), all provoke service employees to demonstrate good customer service, whereas, manufacturing employees received less benefit from these sources of motivation or KSA development.

Furthermore, service organizations heavily depend upon the employee-customer relationship. Consequently, service organizations should also pay attention to manage customers effectively beside the employee management (Bowen, 1986). From the above discussion, that does not mean that HPWS is less beneficial for manufacturing work in contrast to the service sector. Combs et al. (2006) argued that some high-performance work practices (HPWPs) are more closely associated with manufacturing work and practices that are signed for services sector have been under investigation. The present study investigates the relationship between the HPWS and employee performance covering discretionary behavior (OCB) and service related behavior in the service sector of Pakistan.

Delery and Shaw, (2001) further argued that HPWS provides the empowerment to employees in addition to motivation and KSAs. This empowerment gained through HPWS brings improvement in the overall service climate (Gelade \& Ivery, 2003) that further support service employees in the provision of super customer services (Schneider et al., 2006). Finally, in addition to this, HPWPs also provide motivational grounds to demonstrate extra-role activities by the service employees that bring the high level of customer satisfaction (Schneider et al., 2006) and Combs et al. (2006) argued that HPWPs more benefitted the service organizations than manufacturing. As per researcher knowledge, only the one study Liao et al. (2009) investigated the impact of HPWS and employee service quality has been reported in the literature so far. They included 8-high performance HR practices in their study but not included selective staffing and empowerment in their HR bundle. Additionally, Liao et al. (2009) examined the relationship of service-related HPWS on employee general service performance from both employee and management perspectives and found that results are different from these two perspectives. It does not reflect the coherent perception of employee and management. In this study, a different set of HR practices have been adopted. Following the above theoretical clues, according to researcher knowledge, the influence of HPWS on the employee service performance has not been investigated earlier especially in the Pakistani context. So this study provides empirical evidence between the relationship between HPWS and employee service performance in the service sector of Pakistan. Thus, the following hypothesis is formulated: 
H1: HPWS has been significantly related to employee service performance in the service sector of Pakistan.

\subsection{HPWS and Organizational Citizenship Behavior (OCB)}

Organizational citizenship behavior (OCB) is related to the individual contributions that exceed beyond the formal role requirements in the workplace and are contractually rewarded job achievements (Smith, Organ, \& Near, 1983). Organ (1988) defined OCB as: "Individual behavior that is discretionary, not directly or explicitly recognized by the formal reward system, and that in the aggregate promotes the effective functioning of the organization. By discretionary, we mean that the behavior is not an enforceable requirement of the role or the job description, that is, the clearly specifiable terms of the person's employment contract with the organization; the behavior is rather a matter of personal choice, such that its omission is not generally understood as punishable (p. 4)".

It has been observed that the major share of the existing research on OCB has been conducted in a manufacturing organization and less evidence from service context are available in the OCB literature. So far social exchange has been the main factor among all the investigated factors and has been considered as a significant predictor of employees' related OCBs (Podsakoff et al., 2000; Cho \& Johanson, 2008).

Over the more than 30 years into the literature (Smith, Organ, \& Near, 1983), the researcher's interest in organizational citizenship behaviors (OCBs) have intensely increased. Podsakoff et al. (2014) reported that more than 2100 articles are available in the OCBs literature and surprisingly more than half published in the previous four years (Institute for Scientific Information, 2013). Rotundo and Sackett (2002) argued that OCB has become widely recognized in organizational behavior literature and has become an important part of employee performance. In his review on unit level OCB, Podsakoff et al. (2014) pointed out that literature on OCBs is not only limited to the organizational behavior but researcher's interest in numerous other disciplines such as sociology, computer science, public administration, marketing, sports science, engineering, communication, healthcare services, and nursing has grown substantially (Institute for Scientific Information, 2013).

Podsakoff et al. (2014) pointed out that major part of previous research has covered the identification of OCBs antecedents and reported that a range of attitudinal variables (for example, organizational commitment, job satisfaction) or perceptual variables (e.g., justice perceptions), leadership-related variables (for example, transactional and transformational behaviors and leader-member exchange), individual differences (For example, extroversion and conscientiousness), and job characteristics (for example, task interdependence and task feedback ) have been found to be important predictors of employee-related OCBs (Organ et al., 2006).

Employees are ready to perform Extra-role behaviors only when social exchange contract describe the relationship between an employee and employer (Paré \& Tremblay, 2007) Snape and Redman (2010) reported that HRM practices positively influence the organizational citizenship behavior in employees from North- East England. This present study has noted that only a few studies are available in which the role of HPWS as an antecedent of OCB behavior have discussed (Sun et al., 2007). They, however, did not label and clearly 
conceptualize the construct of collective OCB and nor did they conceptualize and investigate the mechanisms from which HPWS links to OCB empirically. A recent multi-level analysis conducted by Snape and Redman, (2010) found the positive influence of HRM practices onorganizational citizenship behavior. They used an HR manager questionnaire covering HPWS approaches such as carefully staff selection, regular performance appraisal, motivation through performance related rewards, training, promotion opportunities, and opportunities to listen to their views but in present study includes different set of high performance work practices such as employee empowerment, information sharing, selective staffing, competency development and performance-based compensation. The present study provides empirical evidence to understand the relationship between HPWS and OCB in the service sector of Pakistan. Thus, the following hypothesis is drawn.

$\mathrm{H} 2$ : HPWS has been significantly related to organizational citizenship behavior among service sector employees of Pakistan.

\subsection{HPWS and PsyCap}

PsyCap is the advance version of the human capital (that is what employees know about their education, experience, etc.) and is related to who employees are (their psychological self) and what they can be in future. It has been viewed that role of PsyCap has been extended from psychology to the workplace especially in the field of human resource management. (Luthans \& Youssef 2004; Luthans et al., 2007b).

PsyCap is defined by Luthans et al. (2007b) as: "An individual's positive psychological state of development that is characterized by: (1) having confidence (self-efficacy) to take on and put in the necessary effort to succeed at challenging tasks; (2) making a positive attribution (optimism) about succeeding now and in the future; (3) persevering toward goals and, when necessary, redirecting paths to goals (hope) in order to succeed; and (4) when beset by problems and adversity, sustaining and bouncing back and even beyond (resiliency) to attain success".

PsyCap comprises on four psychological dimensions such as "hope (individual's ability to persevere toward a goal), efficacy (confidence to take on and put in the necessary effort to be successful at challenging tasks), resilience (being able to sustain and bounce back to attain success when beset by problems and adversity and optimism (a positive expectation about succeeding now and in the future (Luthans et al., 2007)".

Avey, Reichard et al. (2011) has found that there is positive association exists between PsyCap and multiple performance measures (objective, self and supervisor evaluations), desirable employee behaviors (citizenship), attitudes (job satisfaction, psychological well-being, organizational commitment). Previous studies reported that PsyCap has a negative relationship with an undesirable employee like as deviant or counterproductive behavior (Norman et al., 2010; Avey et al., 2008).

Bases on the 179 sample from the United States, an exploratory study by Peterson et al. (2011) found that employee performance is foster by the PsyCap among the retail workers of a large financial service organization. Similarly, Rego et al. (2010) reported that overall PsyCap influence performance of Portuguese civil servants. 
Researchers have developed a consensus that PsyCap is an important predictor of both individual and group level performance (Gooty et al., 2009; Walumbwa et al, 2010, 2011). Although previous studies have succeeded to build positive linkage between PsyCap and employee performance empirically evidence from different cultures (Luthans et al., 2007; Walumbwa et al., 2011; Walumbwa et al., 2010, Peterson et al., 2011) but this cross-sectional study focuses on the relationship of HPWS and PsyCap. Newman et al. (2014) has pointed out that future studies should examine the role of human resource management in the development of PsyCap. Therefore, the following hypothesis is drawn:

H3: HPWS has been significantly related to psychological capital among service sector employees of Pakistan.

\subsection{Mediating Role of Psychological Capital}

Avey et al., (2014) argued that literature on PsyCap had paid more attention to the outcomes and antecedents of PsyCap, instead of the mediating role of PsyCap. No doubt that recent research studies have started to recognize the possible mediators between the relationship of PsyCap and potential outcomes, for example, psychological empowerment (Avey et al., 2008), but much research is still required in this area.

Previous studies have investigated the mediating role of PsyCap between the various outcomes and antecedents at different levels (such as individual, group and organizational). Luthans et al. (2008) revealed that the relationship of supportive organizational climate and subsequent job performance is fully mediated by the PsyCap.

Recently, Wang et al. (2012) found that the relationship between dimensions of burnout and work-family conflict is partially mediated by PsyCap. Few studies have examined the relationship of leadership styles and work outcomes through the mediation of PsyCap (McMurray et al., 2010; Rego et al., 2012c). Similarly, Gooty et al. (2009) reported a relationship of transformational leadership and follower's organizational citizenship behaviors (OCBs) and job performance is fully mediated through the PsyCap.

Walumbwa et al. (2011) reported that team- level collective PsyCap is to fully mediate the relationship of organizational citizenship behavior, authentic leadership, and team level performance. A recent study concludes that PsyCap of the follower is positively associated with PsyCap of leader and the relationships between leader and follower is mediated by the quality of their relationship (Story et al., 2013).

In their conceptual paper, Singh and Gupta (2010) presented arguments from the past studies and focused on the examination of PsyCap as a mediating variable between HPWS and OCB relationship. They also highlighted that there is a possibility of negative impacts of HPWS and the potential capacities of PsyCap can mitigate these negative effects.

Previous studies have investigated the influence of HPWS on employee performance and PsyCap on employee performance separately but none of the studies has investigated the influence of HPWS on the employee service performance with the mediating role of PsyCap. Thus, this study posits the following hypothesizes:

H4a: Psychological capital has been mediated the relationship of HPWS and employee service performance in the service sector of Pakistan. 
H4b: Psychological capital has been mediated the relationship of HPWS and employee service performance in the service sector of Pakistan.

Therefore, this study assumes that the influence of HPWS on employee performance and OCB is mediated by PsyCap (see Figure 1).

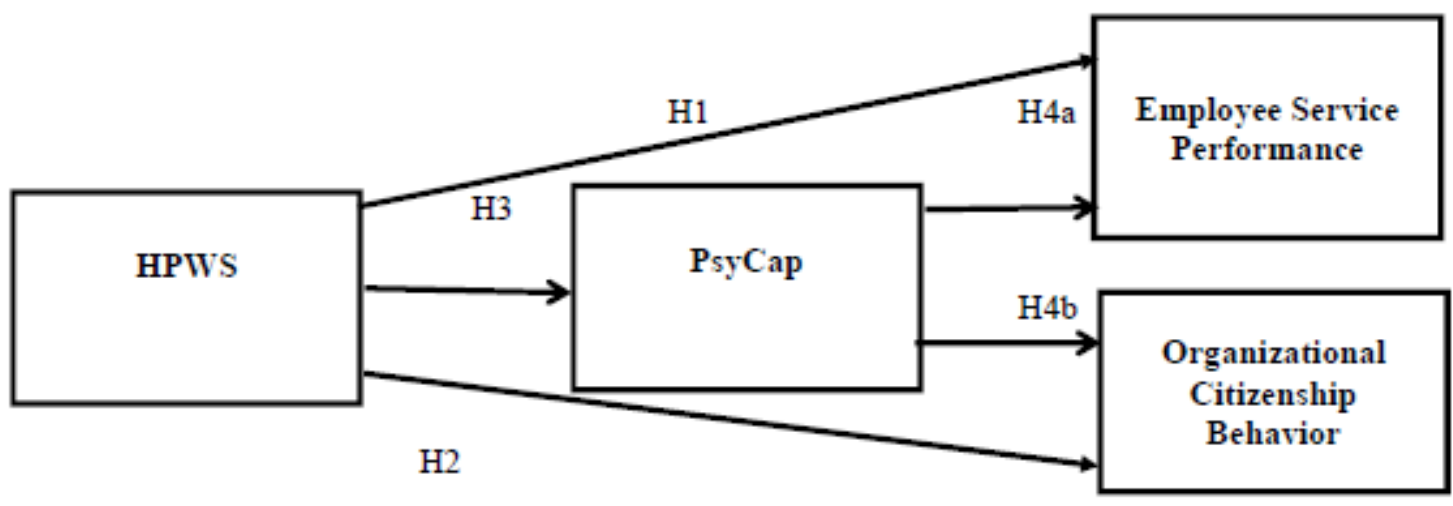

Figure 1. Theoretical framework

\section{Research Methodology}

\subsection{Sample and Procedure}

In this present study, the target population includes the front line employees working in the service sector of Pakistan. The target population includes the employees working in five industries banking, insurance, telecommunication, airline, and hotels. The study design was cross-sectional in nature and data was collected through a self-administered survey. As the population framework was unknown and the sample size was calculated with the help of response to item theory which was total 510 (ten times of the items) as suggested by (Lord, 1980). Questionnaires were distributed among five service industries which are core contributor of GDP in Pakistan. There are thousands of employees working in the service sector in public as well as private organizations. As the population framework is unknown so the complete randomness cannot be achieved and sampling was done at two-level. At the first stage, the proportionate stratified sampling technique was used in which five strata were made and employees were selected according to the size of the industry. At the second stage, convenience sampling was used to get survey filled from employees. Such technique was also used by Gim, (2016) and Shi et al. (2017) in their studies. Data was collected from the organization located in Lahore city which falls in these five categories of service industries. Data was collected through physical visits and questionnaires were filled at spot Data was collected in December 2016.

With the help of response to item theory Lord (1980), so we had enough data for making an inference (510 distributed, 380 returned filled with response rate $74 \%, 371$ that was finally used for analysis). Moreover, the reliability of all the measureswas well above the threshold values so the results are generalizable specifically in social sciences context. CFA/Measurement model was fitted for factorial validity. Moreover, these measures were 
widely used in previous studies such as PsyCap: Luthans et al. (2007), HPWS; Zhong et al. (2015), ESP: Tang and Tang (2012), OCB: Haque and Aslam (2011) and ethical approval to use all scales was also granted by the authors respectively.

Out of 371 total respondents, 267 males (72\%) and 104 females (28\%) participated in this study. Respondents median age was 26-35 year and 228 (approximately 61\%) possessed 16-year education. 295 participants $(80 \%)$ were in non-managerial role and only $76(20 \%)$ were in a non-managerial role. 131 (approximately 35\%) respondents hold less than 5 years working experience and 151 participants (approximately 41\%) possess 5 to 10 -year working experience including the 201 participants $(54 \%)$ with less than 5 years job tenure followed by 123 (33\%) with 5-10 years job tenure with current employer. The median income of respondents was between 20000 to 50000 Pak rupees with 241 respondents (65\%). Finally, 148 participants (approximately 40\%) were from the banking sector followed by 87 respondents $(23 \%)$ from the insurance sector. 68 respondents $(18 \%)$ were from telecommunication, 40 from $(11 \%)$ were from the airline and lastly, 28 respondents (approximately $8 \%$ ) participated from the hospitality sector.

\subsection{Measures}

The present study used the bundle of five HR practices such as selective staffing, competency development, performance-based compensation, information sharing, and empowerment. To measure these five dimensions, different scales developed by previous researches have been employed. Empowerment was measured with a scale developed by Murphy and Murrmann (2009). Extensive training or competency development andperformance-based compensation was measured through scale developed by Sun et al., (2007). Finally, Information sharing and selective staffing were measured through the scale developed by Zacharatos (2005). All these five dimensions of HPWS were measured at 5-point Likert scale ranging from $1=$ Strongly Disagree, 2 = Disagree, $3=$ Neutral, $4=$ Agree and $5=$ Strongly Agree.

PsyCap is the mediating variable for this study and is comprised of four dimensions i.e. hope, efficacy, resilience, and optimism. A 24-items (6 for each dimension) measuring instrument developed by Luthans et al. (2007) is used in this study. Reliability from previous studies ranged from .70 to .85 which is satisfactory for any measuring instrument. Permission and rights to collect data through this instrument have also granted by the author after detailed submission of study objectives, variables, and methodology at www.mindsgarden.com. All 24 psychological items were measured on 5-point Likert type scale i.e. $1=$ Strongly Disagree, $2=$ Disagree, $3=$ Neutral, $4=$ Agree and $5=$ Strongly Agree Three items were measured on reverse scaling.

Employee service performance consisted of 10 items instrument developed by the Bettencourt and Brown (1997) is used. Cronbach's Alpha in previous studies was ranged from .80 to .87 for employee service performance scale. Permission and the original version of the instrument have also been provided by the author. All items of employee service performance were measured on 5-point Likert type scale i.e. $1=$ Strongly Disagree, $2=$ Disagree, $3=$ Neutral, $4=$ Agree and $5=$ Strongly Agree .

Finally, the 11-items instrument to measure organizational citizenship behavior developed by Podsakoff and Philip, (1990) and Williams and Anderson, (1991) was used in this study. 


\section{Macrothink}

Loading of all the items is found to be significant as a single factor in the previous studies (Podsakoff \& Philip, 1990, Williams \& Anderson, 1991). Like the other measuring scales of the study, items of OCBs were also measured at 5-point Likert scale, for example, $1=$ Strongly Disagree, $2=$ Disagree, $3=$ Neutral, $4=$ Agree and $5=$ Strongly Agree.

\section{Results}

Data analysis for this study was carried out in four steps by using the SPSS 21 and AMOS 21 . First, means and standard deviation were measured and compared for all the four variables such as HPWS, PsyCap, employee service performance, and OCB. Second, the association among the variables were measured through bivariate correlation analysis. Thirdly, CFA was performed to check the factor loading of all items in their respective scales. Finally, hypothesis testing was carried out through the structural equation modeling (SEM) and the bootstrapping method was used to check the mediation of PsyCap, service performance and OCB.

Table 1 represents the mean, standard deviation and correlation analysis for all the independent and dependent variables. HPWS as an independent variable was found to be positive and statistically significantly associated with employee service performance, PsyCap, and organizational citizenship behavior.

Table 1. Mean, standard deviation and correlation matrix

\begin{tabular}{lllllll}
\hline Sr. No. & Variable & Mean & S.D & 1 & $\mathbf{2}$ & 3 \\
\hline 1 & PsyCap & 3.60 & 0.40 & & & \\
2 & HPWS & 3.41 & 0.42 & $.39^{* *}$ & & \\
3 & ESP & 3.59 & 0.47 & $.42^{* *}$ & $.46^{* *}$ & \\
4 & OCB & 3.65 & 0.54 & $.48^{* *}$ & $.43^{* *}$ & $.59^{* *}$ \\
\hline
\end{tabular}

**. Correlation Significant at the 0.01 level (2-tailed).

Results of bivariate correlation clearly indicates PsyCap is significantly correlated with HPWS $\left(.39^{* *}\right)$, ESP $\left(.42^{* *}\right)$, OCB $\left(.48^{* *}\right)$, whereas HPWS is significantly associated with ESP $\left(.46^{* *}\right)$ and OCB $\left(.43^{* *}\right)$. The highest correlation was observed between ESP and OCB $\left(.59^{* *}\right)$. Hence, there is a significant positive association exists between HPWS, PsyCap, employee service performance, and organizational citizenship behavior.

In the second stage, confirmatory factor analysis was carried out to check the factor loading of all scales by using the AMOS 21. The model found to be reasonably fit and all ratios meet the threshold values. Fitness rations are presented in below Table 2

Table 2. Fitness ratios of model

\begin{tabular}{llllrrl}
\hline $\boldsymbol{C M I N}$ & DF & CMIN/DF & GFI & NFI & CFI & RMSEA \\
\hline 828.17 & 453 & 1.83 & .893 & .915 & .933 & .047 \\
\hline
\end{tabular}




\section{Macrothink Institute ${ }^{\text {TM }}$}

As evident from the above-mentioned Table 2, it has been observed that all the ratios GFI (.893) NFI (.915), CFI (.933) have achieved the acceptable limit (Hu \& Bentler, 1999). The value of RMSEA is close to .047 and CMIN/DF is less than 2. The four items of HPWS were deleted due to the less factor loading $\leq .40$ and two items of OCB was deleted due to less factor loading. All the items of employee service performance were loaded significantly and three items of PsyCap were deleted due to fewer regression weights. Finally, proposed hypotheses were tested through the structural equation modeling (SEM). First of all, the SEM model fitness ratios were measured to calculate the model fitness and then related hypotheses were tested

All the SEM ratios are presented in table 3. This following model fitness measures was produced by the model: $\mathrm{CMIN}=3.139, \mathrm{DF}=5, \mathrm{CMIN} / \mathrm{DF}=.628, \mathrm{GFI}=.982, \mathrm{NFI}=.945$, $\mathrm{CFI}=.973$, and RMSEA $=.048$. The values of CFI, GFI are closed to 1.0, which reflect the good model fitness. Value of CMIN/DF is less than 5 and RMSEA values are less than .08 which further confirms that the model is absolutely fit. The main reason for good model fitness is that all the paths in the model are significant. Hypothesis 1 is related to the positive relationship between HPWS and employee service performance and results indicate the full support to this hypothesis as HPWS was found positively associated with employee service performance $(\beta=.47, \mathrm{P} \leq .01)$. Hypothesis 2 was proposed to measure the positive association between HPWS and OCB, which gained full support as HPWS was reported to be positively related to organizational citizenship behavior $(\beta=.46, \mathrm{P} \leq .01)$. Similarly, Hypothesis 3 was posited to examined the positive relationship between HPWS and PsyCap which was found to be fully supported as HPWS was found to positively related with PsyCap $(\beta=.40, \mathrm{P} \leq .01)$. Hence, all the hypotheses $\mathrm{H} 1, \mathrm{H} 2$ and $\mathrm{H} 3$ related to the direct relationship were accepted. The regression weights of each path are also mentioned in Figure 2.

Table 3. Fitness ratios of model

\begin{tabular}{llllccc}
\hline $\boldsymbol{C M I N}$ & $\boldsymbol{D F}$ & $\boldsymbol{C M I N / D F}$ & $\boldsymbol{G F I}$ & $\boldsymbol{N F I}$ & $\boldsymbol{C F I}$ & $\boldsymbol{R M S E A}$ \\
\hline 3.139 & 5 & .628 & .982 & .945 & .973 & .048 \\
\hline
\end{tabular}

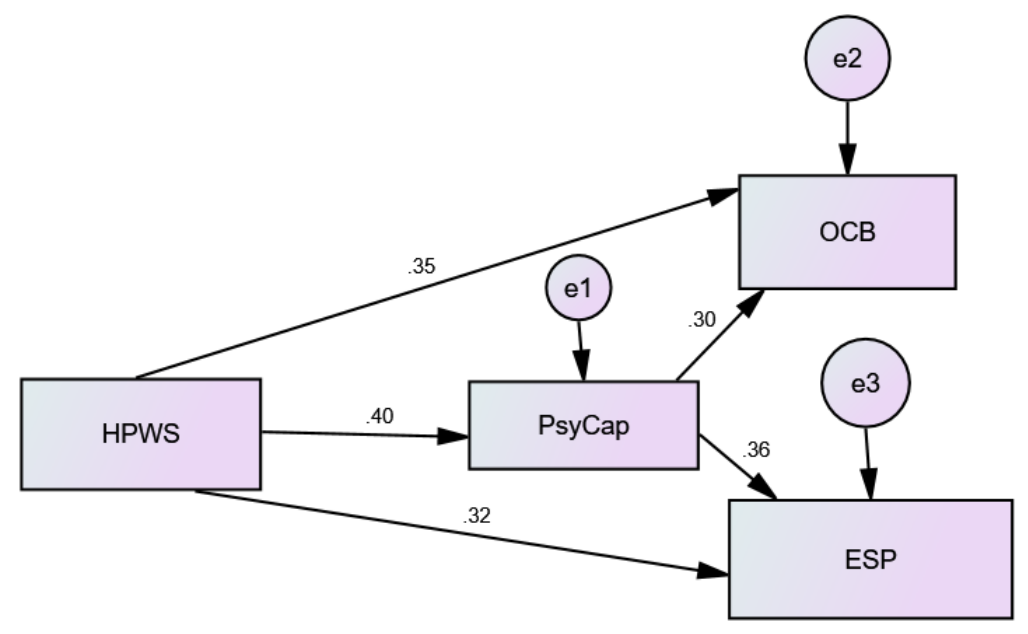

Figure 2. Structural equation model 
For the identification of partial or full mediation analysis of PsyCap between the relationship of HPWS, employee service performance (ESP) and organizational citizenship behavior (OCB), a latest statistical technique called "bootstrapping method" introduced by (Efron, 1979) was used. Bootstrapping has more power as compare to Sobel test in the measurement of indirect paths especially in the small samples (Shrout \& Bolger, 2002). The standardized direct effect of HPWS on employee service performance is positively significant $(\beta=.001, \mathrm{P}$ $\leq .05)$ and standardized direct effect of HPWS on OCB is positively significant $(\beta=.001, \mathrm{P}$ $\leq .05)$. The standardized indirect effect of HPWS on employee service performance is positively significant $(\beta=.001, \mathrm{P} \leq .05)$ and effect of HPWS is positively significant $(\beta$ $=.001, \mathrm{P} \leq .05)$. It has found that $\mathrm{p}$ values of all the direct and indirect paths are less than .05 and value of total direct path is also less than .05 which indicate that H4a is supported and accepted.

Similarly, to determine the mediation of PsyCap between the link of HPWS and organizational citizenship behavior, bootstrap results revealed that standardized direct effect of HPWS on OCB is positively significant $(\beta=.001, \mathrm{P} \leq .05)$. The standardized indirect effect of HPWS on OCB is positively significant $(\beta=.001, \mathrm{P} \leq .05$, whereas all the direct path is significant. It has found that $p$ values of all the direct and indirect paths are less than .05 and value of total direct path is also less than .05 which indicate that $\mathrm{H} 4 \mathrm{~b}$ is supported and accepted. Findings revealed that PsyCap partially mediates the relationship between HPWS and organizational citizenship behavior with $95 \%$ bias-corrected and accelerated (BCA) bootstrap confidence interval (CI) and $\mathrm{H} 4 \mathrm{~b}$ is accepted.

\section{Conclusion and Discussion}

The objective of this study was to investigate the impact of HPWS on the service performance, organizational citizenship behavior (OCB) and PsyCap among the service sector employees of Pakistan. The current study has also examined whether PsyCap mediates the relationship of HPWS with employee service performance and OCB among the employees from service sector of Pakistan. Findings of this study are fully consistent with the study objectives which have several practical applications for academic practitioners and human resource managers. Findings of this study strengthen the argument that HPWS influence the discretionary efforts of employees such as organizational citizenship behavior previously suggested by Becker et al. (1997).

Service organizations around the world are interested to increase the service performance and discretionary behaviors of their employees to attain a competitive advantage. Service firms are heavily depended on their customer services. Recent statistics show the tremendous growth and vital contribution of the service sector in the economy of Pakistan. It has been forecasted that this momentum and positive trends will continue in the coming years. It is necessary to consider the ways to increase the employee performance especially related to service and this study indicates that service performance of employees can be enhanced if HPWS is implemented properly.

Findings are consistent with the recent study by Miao et al. (2015) that HPWS can enhance the PsyCap and this study further confirms the mediating role of PsyCap between the HPWS and employee service performance both task performance (service) and contextual performance (OCB) which Miao et al. (2015) did not investigated. Findings related to HPWS 
confirms the theoretical linkage described by Singh and Gupta (2010) with empirical evidence from the service sector of Pakistan.

Findings of the relationship between HPWS and OCB are consisted of a recent study by Kehoe and Wright (2013) but they applied a different set of HR practice which this study used. Findings of this study cover the literature gap identified by Newman et al. (2014) which called to investigate the relationship between HPWS and PsyCap. Finding revealed that HPWS positively influence the PsyCap. As pointed by (Avey, 2014) in his study that there is a dearth of research available on the antecedent of psychological, so this study presented the HPWS as a predictor of PsyCap and empirically confirmed this relationship which he also called the left side of PsyCap.

To the researcher knowledge, this study is among the pioneer studies investigating the influence of HPWS on employee service performance and organizational citizenship behavior (OCB) through the mediating role of PsyCap, especially in the Pakistani context. Kehoe \& Wright (2013) reported the similar findings which are consistent with this study, in which they found that high-performance HR practices have a positive association with organizational citizenship behavior.

Findings also support the results of a recent study by Karatepe (2013), in which he concluded that HPWPs such as training, reward, empowerment enhance work engagement and resultantly work engagement increases the employee service performance (extra-role performance and on job) among hotel employees in Romania but Karatepe (2013) treated the high-performance work practices as separately not considered as a whole HPWS.

This study also further advance the findings of Chung et al. (2003) that not only HR best practices like training and development, recruitment and selection, compensation and rewards is the important ingredient for effective service quality but HPWS is also enhanced the employee service performance. Findings are also consistent with the study results of Snape and Redman (2010) which reported that HRM practices have a positive impact on organizational citizenship behavior among employees from North- East England.

Finally, study findings strengthen the arguments presented by Schneider et al. (2006) that HPWPs not only provide motivational incentives to service workers to engage in extra-role activities empirically. Findings of the study also confirm the arguments by Muse et al. (2008) argued that HPWS helps in the creation of an environment where PsyCap develops and in turn employees develop their workplace-related positive attitudes and behaviors. In this study, this is evident that HPWS developed the environment which leads to the development of PsyCap and then enhanced the service performance and OCB among service sector employees in Pakistan. This study also supports the notion of Caza et al. (2009) that HR practices promote a high level of employee's PsyCap empirically.

As this present study concludes that HPWS is found to be significantly influence the employee service performance and OCB which is exactly consistent with the arguments presented by Chuang and Liao (2004) that "HRM practices provide employees with the skills, resources, discretion they need to meet customer demands, making them able to deliver high-quality service and these practices may motivate employees to be more willing to provide good performance (Chuang \& Liao, 2004)". 


\section{Macrothink}

This study attempted to fill the recent literature gap pointed out by Avey et al. (2014) on the mediating role of PsyCap, thus current study provides the HPWS as an antecedent of PsyCap and also investigate the mediating role of PsyCap between the relationship of HPWS, employee service performance, and OCB. Study findings support the theoretical linkage presented by Singh and Gupta (2010) empirically from the sample taken from service sector of Pakistan and confirms that PsyCap is found to be mediating role between the relationship of HPWS and OCB. Results are also consistent with the findings of Walumbwa et al. (2011) that PsyCap adds positive value to employee's positive behavior especially OCB. Relationship of HPWS with the employee service performance and organizational citizenship behavior (OCB) has been viewed from the social exchange theory perspectives. Thus, application of social exchange theory (Blau, 1964) also confirmed through the findings of this study results. This study also supports the arguments by Datta et al. (2005) that HPWS is the major source of competitive advantage for an organization and can improve the performance at organizational-level (Wright et al., 2005). This study also advances the arguments presented by Collins andSmith (2006) in a service context that HPWS increase the firm performance by creating the service related performance that enhances the employee capabilities and firm competitive advantage.

\section{Recommendations}

The study findings recommend that service organization in Pakistan should implement the high-performance work practices to increase not only service related performance of their employees but also organizational citizenship behavior and PsyCap significantly. Moreover, it is suggested that use of PsyCap in the selection process of employees and implementation of high-performance work practices can further increase the service performance and organizational citizenship behavior (OCB) in service organizations. The findings of study emphasis on the implementation of high-performance work practice such as selecting staffing, competency development, performance-based compensation, empowerment, and information sharing to increase the service performance which is desired by every service firms around the globe.

The study also recommends that apart from HPWS, if service organizations take steps to improve PsyCap, it will foster service-related performance as PsyCap is a strong predictor of employee service performance than HPWS. It has been also recommended that both HPWS and PsyCap promote employee service performance and organizational citizenship behavior (OCB).

\section{Limitations}

Apart from significant findings, the current study also highlights some issues and limitations which needs to be addressed in future research. Firstly, a structured questionnaire was used to collect the data to examine the relationship between the study variables for this study. A longitudinal or experimental research might be helpful to further authenticate the causal relationship among the variables of the study, particularly related to HPWS and employee service performance which has less evidence in previous literature. Secondly, all the study variable HPWS, employee service performance, organizational citizenship behavior (OCB) and PsyCap (PsyCap) was measured through self-reported constructs. Future studies should measure these variables through supervisor rated version of each measure. Thirdly, this study 
has adopted only five high-performance work practices, future studies with the inclusion of more practices will present a better picture of HPWS in the service sector of Pakistan.

Fourth, this present study has treated employee service performance as a single construct comprises of two dimensions in-role service performance and extra-role service performance. Future research should investigate the relationship between HPWS and dimension of employee service performance separately. Similarly, the present study used organizational citizenship behavior as a whole construct comprises on individual citizenship behavior and organizational citizenship behavior. Future research should examine the relationship of variables with dimensions of organizational citizenship behavior separately.

\section{References}

Appelbaum, E., Bailey, T., Berg, P., \& Kalleberg, A. L. (2000). Manufacturing advantage: Why high-performance work systems pay off. Ithaca, NY: Cornell University Press.

Avey, J. B., Hughes, L. W., Norman, S. M., \& Luthans, K. (2008). Using positivity, transformational leadership and empowerment to combat employee negativity. Leadership and Organization Development Journal, 29, 110-126. https://doi.org/10.1108/014377308 10852470

Avey, J. B., Reichard, R. J., Luthans, F., \& Mhatre, K. H. (2011). A meta-analysis of the impact of positive psychological capital on employee attitudes, behaviors, and performance. Human Resource Development Quarterly, 22, 127-152. https://doi.org/10.1002/hrdq.20070

Avey, J. B. (2014). The Left Side of Psychological Capital: New Evidence on the Antecedents of PsyCap. Journal of Leadership \& Organizational Studies, 21(2), 141-149. https://doi.org/10.1177/1548051813515516

Bailey, T. (1993). Discretionary effort and the organization of work: Employee participation and work reform since Hawthorne. Paper prepared at Columbia University for the Sloan Foundation.

Barney, J. B., \& Wright, P. M. (1998). On becoming a strategic partner: The role of human resources in gaining competitive advantage. Human Resource Management, 37, 31-46. https://doi.org/10.1002/(SICI)1099-050X(199821)37:1\%3C31::AID-HRM4\%3E3.0.CO;2-W

Baron, R. M., Kenny, D.A. (1986). The moderator-mediator variable distinction in social psychological research: conceptual, strategic, and statistical considerations. Journal of Personality and Social Psychology, 51, 1173-1182. https://doi.org/10.1037/0022-3514.51.6. 1173

Batt, R. (2002). Managing customer services: Human resource practices quit rates, and sales growth. Academy of Management Journal, 45, 587-597. https://doi.org/10.5465/3069383

Baumeister, R. F. (1982). A self-presentational view of social phenomena. Psychological Bulletin, 91, 3-26. https://doi.org/10.1037/0033-2909.91.1.3

Becker, B. E., Huselid, M. A., Pickus, P. S., \& Spratt, M. F. (1997). HR as a source of shareholder value: Research and recommendations. Human Resource Management, 36(1), 39-47. https://doi.org/10.1002/(SICI)1099-050X(199721)36:1\%3C39::AID-HRM8\%3E3.0. CO;2-X

Bettencourt, L. A., \& Brown, S. W. (1997). Contact employees: relationships among workplace fairness, job satisfaction and prosocial service behaviors. Journal of Retailing, 73, 
39-61. https://doi.org/10.1016/S0022-4359(97)90014-2

Blau, P. (1964). Exchange and power in social life..New York: Wiley.

Borman, W. C., \& Motowidlo, S. J. (1993). Expanding the criterion domain to include elements to contextual performance. In N. Schmitt, \& W. C. Borman (Eds.), Personnel selection in organizations (pp. 71-98). San Francisco: Jossy-Bass.

Bowen, D. E. (1986). Managing customers as human resources in service organizations. Human Resource Management, 25, 372-384. https://doi.org/10.1002/hrm.3930250304

Bowen, D. E., \& Waldman, D. A., (1999). Customer-driven employee performance. In D. A. Ilgen, \& E. D. Pulakos (Eds.), The changing nature of performance (pp. 154-191). San Francisco: Jossey-Bass.

Campbell, J. P., McCloy, R. A., Oppler, S. H., \& Sager, C. E. (1993). A theory of performance. In N. Schmitt, \& W. C. Borman (Eds.), Personnel Selection in Organizations (pp. 35-70) San Francisco Jossey-Bass.

Caza, A., McCarter, M. W., Hargrove, D., \& Wad, S. R. (2009). Third party effects of Psychological Capital: Observer attributions and responses. Academy of Management Proceedings, 1-6. https://doi.org/10.5465/ambpp.2009.44265238

Chuang, C., \& Liao, H. (2010). Strategic human resource management in service context: Taking care of business by taking care of employees and customers. Personnel Psychology, 63(1), 153-168. https://doi.org/10.1111/j.1744-6570.2009.01165.x

Chung-Herrera, V.,Enz, C. \& Lankau, L. (2003).Grooming future hospitality leaders: A competencies model. Cornell Hotel and Restaurant Administration Quarterly, 44(3), 17-25. https://doi.org/10.1177/001088040304400302

Collins, C. J., \& Smith, K. G. (2006). Knowledge exchange and combination: The role of human resource practices in the performance of high-technology firms. Academy of Management Journal, 49, 544-560. https://doi.org/10.5465/amj.2006.21794671

Combs, J., Lui, Y., Hall, A. and Ketchen, D. (2006). How much do high-performance work practices matter? A meta-analysis of their effects on organizational performance. Personnel Psychology, 59, 501- 28. https://doi.org/10.1111/j.1744-6570.2006.00045.x

Datta, D. K., Guthrie, J. P., \& Wright, P. M. (2005). Human resource management and labor productivity: Does industry matter. Academy of Management Journal, 48, 135-145. https://doi.org/10.5465/amj.2005.15993158

Delery, J. E, \& Shaw, J. D. (2001). The strategic management of people in work organizations: Review, synthesis, and extension. In G. R. Ferris (Ed.), Research in personnel and human resources management, 20, 165-197. https://doi.org/10.1016/S0742-7301(01)20003-6

Dyer, L., \& Reeves, T. (1995). Human resource strategies and firm performance: What do we know and where do we need to go? International Journal of Human Resource Management, 6, 656-670. https://doi.org/10.1080/09585199500000041

Efron, B. (1979). Bootstrap methods: Another look at the jackknife. Annals of Statistics, 7, 1-26. https://doi.org/10.1214/aos/1176344552

Erickson, M., Hanlon, M., \& Maydew, E. (2006). Is there a link between executive compensation and accounting fraud? Journal of Accounting Research, 44, 113-143. 
https://doi.org/10.1111/j.1475-679X.2006.00194.x

Ferris, G. R., Arthur, M. M., Berkson, H. M., Harrel-Cook, G., \& Fink, G. (1998). Toward a social context theory of the human resource management-organizational effectiveness relationship. Human Resource Management Review, 8, 235-264. https://doi.org/10.1016/ S1053-4822(98)90004-3

Gelade, G. A., \& Ivery, M. (2003). The impact of human resource management and work climate on organizational performance. Personnel Psychology, 56, 383-404. https://doi.org/10.1111/j.1744-6570.2003.tb00155.x

Gim, T. T-H., (2016). Land use, travel utility and travel behaviour: An analysis from the perspective of the positive utility of travel, Paper in Regional Sciences, 1-24. https://doi.org/10.1111/pirs.12239

Gooty, J., Gavin, M., Johnson, P., Frazier, L., \& Snow, D. (2009). In the eyes of the beholder: Transformational leadership, positive psychological capital and performance. Journal of Leadership and Organization Studies, 15, 353-357. https://doi.org/10.1177/1548051809 332021

Gupta, V., \& Singh, S. (2010). High Performance HRM practices, organizational citizenship behavior and positive psychological capital: A relational perspective. Indian Institute of Management, WPS 2010-11/16.

Guthrie, J. P. (2001). High-involvement work practices, turnover, and productivity: Evidence from New Zealand. Academy of Management Journal, 44, 180-190. https://doi.org/10.2307/3069345

Guthrie, J. P., Flood, P. C., Liu, W., \& MacCurtainc, S., (2009). High performance work systems in Ireland: human resource and organizational outcomes. The International Journal of Human Resource Management, 20(1), 112-125. https://doi.org/10.1080/09585190 802528433

Haque A, \& Aslam MS (2011). Influence of Distributive Justice on Organizational Citizenship Behaviors: Mediating Role of Emotional Exhaustion and Organizational Attachment. International Journal of Business and Social Science, 2(1), 155-165.

Heskett, J. L., Sasser, W. E., \& Schlesinger, L. A. (1997). The service profit chain: How leading companies link profit and growth to loyalty, satisfaction, and value. New York: Free Press.

Hu, L., \& Bentler, P. M. (1999). Cutoff criteria for fit indexes in covariance structure analysis: conventional criteria versus new alternatives. Structural Equation Modeling, 6, 1-55. https://doi.org/10.1080/10705519909540118

Huselid, M. A. (1995). The impact of human resource management practices on turnover, productivity, and corporate financial performance. Academy of Management Journal, 38, 635-672. https://doi.org/10.2307/256741

Karatepe, M. O. (2013). High-performance work practices and hotel employee performance: The mediation of work engagement. International Journal of Hospitality Management, 32, 132-140. https://doi.org/10.1016/j.ijhm.2012.05.003

Kehoe, R. R., \& Wright, M. P., (2013). The Impact of High-Performance Human Resource 
Practices on Employees' Attitudes and Behaviors. Journal of Management, 39(2), 366-391. https://doi.org/10.1177/0149206310365901

Kroon, B., Voorde, V. D., \& Veldhoven, M. V., (2009). Cross-level effects of high-performance work practices on burnout. Personnel Review, 38(5), 509-525. https://doi.org/10.1108/00483480910978027

Liao, H., Toyo, K., Lepak, D., \& Hong, Y. (2009). Do they see eye to eye? Management and employee perspectives of high performance work system and influence processes on service quality. Journal of Applied Psychology, 94(2), 371-391. https://doi.org/10.1037/a0013504

Liao. H., \& Chuang. A. (2004). A multilevel investigation of factors influencing employee service performance and customer outcomes. Academy of Management Journal, 47(1), 41-58. https://doi.org/10.5465/20159559

Liu, L., Chang, Y., Fu, J., Wang, J., \& Wang, L. (2012). The mediating role of psychological capital on the association between occupational stress and depressive symptoms among Chinese physicians: A cross-sectional study. BMC Public Health, 12, 219-227. https://doi.org/10.1186/1471-2458-12-219

Lord, F. M. (1980). Applications of item response theory to practical testing problems. Mahwah, NJ: Lawrence Erlbaum Associates, Inc.

Luthans, F. \& Youssef, C. M. (2004). Human, social, and now positive psychological capital management: Investing in people for competitive advantage. Organizational Dynamics, 33(2), 143-60. https://doi.org/10.1016/j.orgdyn.2004.01.003

Luthans, F., Avey, J. B., Clapp-Smith, R., \& Li, W. (2008). More evidence on the value of Chinese workers' psychological capital: A potentially unlimited competitive resource? International Journal of Human Resource Management, 19, 818-827. https://doi.org/10.1080/ 09585190801991194

Luthans, F., Avolio, B. J., Avey, J. B., \& Norman, S. M. (2007). Positive psychological capital: Measurement and relationship with performance and satisfaction. Personnel Psychology, 60, 541-572. https://doi.org/10.1111/j.1744-6570.2007.00083.x

Luthans, F., Youssef, C. M., \& Avolio, B. J. (2007). Psychological capital: Developing the human competitive edge. Oxford, UK: Oxford University Press.

McMurray, A. J., Pirola-Merlo, A., \& Sarros, J. C. (2010). Leadership, climate, psychological capital, commitment, and wellbeing in a non-profit organization. Leadership and Organization Development Journal, 31, 436-457. https://doi.org/10.1108/0143773101105 6452

Miao, R., Zhou, W., Bozionelos, N., \& Pan, J., (2015). High-Performance Work System, Psychological Capital and Employee Attitude: A Chinese Study. Academy of Management Journal. https://doi.org/10.5465/ambpp.2014.55

Mills, P. K., Chase, R. B. \& Margulies, N. (1983). Motivating the Client/Employee System as a Service Production Strategy. Academy of Management Review, 8(2), 301-310. https://doi.org/10.2307/257758

Murphy, K., S., \& Murrmann, S., (2009). The Research Design Used to Develop a High Performance Management System Constructs for US Restaurant Managers. International 
Journal of Hospitality Management, 28 (4), 547-555. https://doi.org/10.1016/j.ijhm.2009. 03.003

Muse, L., Harris, S. G., Giles, W. F., \& Feild, H. S. (2008). Work-life benefits and positive organizational behavior: Is there a connection? Journal of Organizational Behavior, 29, 171-192. https://doi.org/10.1002/job.506

Newman, A., Ucbasaran, D., Zhu, F., \& Hirst, G., (2014). Psychological capital: A review and synthesis. Journal of Organizational Behavior, 35, 120-138. https://doi.org/10.1002/job.1916

Nishii, L. H., Lepak, D. P., \& Schneider, B. (2008). Employee attributions of the "why" of HR practices: Their effects on employee attitudes and behaviors, and customer satisfaction. Personnel Psychology, 61, 503-545. https://doi.org/10.1111/j.1744-6570.2008.00121.x

Norman, S. M., Avey, J. B., Nimnicht, J. L., \& Graber-Pigeon, N. P. (2010). The interactive effects of psychological capital and organizational identity on employee citizenship and deviance behaviors. Journal of Leadership and Organization Studies, 17, 380-391. https://doi.org/10.1177/1548051809353764

Organ, D. W. (1988). Organizational citizenship behavior: The Good Soldier Syndrome. Lexington, MA: Lexington Books.

Organ, D. W., Podsakoff, P. M., \& MacKenzie, S. B. (2006). Organizational Citizenship Behavior. Its Nature, Antecedents, and Consequences. Thousand Oaks, CA: Sage.

Paré, G., \& Tremblay, M. (2007). The influence of high-involvement human resources practices, procedural justice, organizational commitment, and citizenship behaviors on information technology professionals' turnover intentions. Group \& Organization Management, 32(3), 326-357.

Peterson, S. J., Luthans, F., Avolio, B. J., Walumbwa, F. O., \& Zhang, Z. (2011). Psychological capital and employee performance: A latent growth modelling approach. Personnel Psychology, 64, 427-450.

Podsakoff Scott, B., \& Philip, M. (1990). Transformational leader behaviors and their effects on followers' trust in leader, satisfaction, and organizational citizenship behaviors. The Leadership Quarterly, 1(2), 107-142.

Podsakoff, N. P., Podsakoff, P. M., MacKenzie, S. B., Maynes, T. D., \& Spoelma. T. M., (2014). Consequences of unit-level organizational citizenship behaviors: A review and recommendations for future research. Journal of Organizational Behavior, 35, 87-119.

Podsakoff, P. M., MacKenzie, S. B., Paine, J. B., \& Bachrach, D. G. (2000). Organizational citizenship behaviors: A critical review of the theoretical and empirical literature and suggestions for future research. Journal of Management, 26, 513-563.

Rego, A., Sousa, F., Marques, C., \& Pina e Cunha, M. (2012c). Authentic leadership promoting employees' psychological capital and creativity. Journal of Business Research, 65, 429-437.

Rego, A., Marques, C., Susana, L., Sousa, F., \& Pina e Cunha, M. (2010). Psychological capital and performance of Portuguese civil servants: exploring neutralizers in the context of an appraisal system. The International Journal of Human Resource Management, 21, 1531-1552. 
Rosenthal, P., Hill, S. \& Peccei, R. (1997). Checking out service: Evaluating excellence, HRM and TQM in retailing. Work, Employment and Society, 11, 481 - 503

Rotundo, M., \& Sackett, P. R. (2002). The relative importance of task, citizenship, and counterproductive performance to global ratings of job performance: A policy-capturing approach. Journal of Applied Psychology, 87: 66-80.

Schneider, B. (2004). Welcome to the world of service management. Academy of Management Executive, 18(2), 144-150.

Schneider, B. \& D. Bowen, (1993). The service organization: Human resources management is crucial. Journal of Organizational Dynamics,21(4): 39-52.

Schneider, B., Ehrhart, M.G., Mayer, D.M., Saltz, J.L.,\& Niles-Jolly, K. (2006). Understanding organizational-customer links in service settings. Academy of Management Journal, 48, 1017-1032.

Shrout, P. E. \& N. Bolger, N. (2002). Mediation in experimental and non-experimental studies: new procedures and recommendations. Psychological Methods, 7, 422-445. https://doi.org/10.1037/1082-989X.7.4.422

Singh, A. K. (2009). HRD practices \& organization culture in India. The Indian Journal of Industrial Relations, 45(2), 243-254.

Smith, C. A., Organ, D. W., \& Near J. P. (1983). Organizational citizenship behavior: Its nature and antecedents. Journal of Applied Psychology, 68, 653-663. https://doi.org/10.1037/ 0021-9010.68.4.653

Snape E. \& Redman T., (2010). HRM Practices, Organizational Citizenship Behaviour, and Performance: A Multi-Level Analysis. Journal of Management Studies, 47(7), 1219-1247. https://doi.org/10.1111/j.1467-6486.2010.00911.x

Sobel, M. E. (1982). Asymptotic interval for indirect effects in structural equation models. In S. Leinhart (Ed.), Sociological methodology 1982 (pp. 290-312). San Francisco: jossey- Bass. https://doi.org/10.2307/270723

Story, J. S. P., Youssef, C. M., Luthans, F., Barbuto, J. E., \& Bovaird, J. (2013). Contagion effect of global leaders' positive psychological capital on followers: Does distance and quality of relationship matter? International Journal of Human Resource Management, 24, 2534-2553. https://doi.org/10.1080/09585192.2012.744338

Sun, L. Y., Aryee, S. \& Law, K. (2007). 'High performance human resource management practices, citizenship behaviour and organizational performance: a relational perspective'. Academy of Management Journal, 50, 558-77. https://doi.org/10.5465/amj.2007.25525821

Tang, T., \& Tang, Y. (2012). Promoting service-oriented organizational citizenship behaviors in hotels: The role of high-performance human resource practices and organizational social climates. International Journal of Hospitality Management, 31, 885-895. https://doi.org/10.1016/j.ijhm.2011.10.007

Takeuchi, R., Lepak, D. P., Wang, H., \& Takeuchi, K. (2009). An empirical examination of the mechanisms mediating between high-performance work systems and the performance of Japanese organizations. Journal of Applied Psychology, 92, 1069-1083. https://doi.org/10.1037/0021-9010.92.4.1069 


\section{Macrothink}

Issues in Economics and Business

ISSN 2377-2301 2019, Vol. 5, No. 2

Van Dolen, W., deRuyter, K., \& Lemmink, J. (2004). An empirical assessment of the influence of customer emotions and contact employee performance on encounter and relationship satisfaction. Journal of Business Research, 57, 437-444. https://doi.org/10.1016/ S0148-2963(02)00277-1

Walumbwa, F. O., Luthans, F., Avey, J. B., \& Oke, A. (2011). Authentically leading groups: The mediating role of collective psychological capital and trust. Journal of Organizational Behavior, 32, 4-24. https://doi.org/10.1002/job.653

Walumbwa, F. O., Peterson, S. J., Avolio, B. J., \& Hartnell, C. A. (2010). An investigation of the relationship between leader and follower psychological capital, service climate and job performance. Personnel Psychology, 63, 977-1003.

Williams, L. J., \& Anderson, S. E. (1991). Job Satisfaction and Organizational Commitment as Predictors of Organizational Citizenship and In-Role Behaviors. Journal of Management, 17, 601-17. https://doi.org/10.1177/014920639101700305

Zacharato, A., Barling, J., \& Iverson, R. D., (2005). High-Performance Work Systems and Occupational Safety. Journal of Applied Psychology, 90(1), 77-93. https://doi.org/10.1037/ 0021-9010.90.1.77

Zhong, L., Wayne, J. S., \& Laiden, R. C. (2015). Job engagement, perceived organizational support, high-performance human resource practices, and cultural value orientations: A cross-level investigation. Journal of Organizational Behavior. https://doi.org/10.1002/job. 2076

\section{Copyright Disclaimer}

Copyright for this article is retained by the author(s), with first publication rights granted to the journal. This is an open-access article distributed under the terms and conditions of the Creative Commons Attribution license (http://creativecommons.org/licenses/by/3.0/). 